\title{
Clival Chordoma in an Indian Female Patient: A Case Report
}

\section{ABSTRACT}

Chordomas are rare tumours that originate anywhere along the craniospinal axis and present various diagnostic hurdles. High recurrence rate even after treatment and tendency to involve other regions within the craniospinal axis make this condition more devastating. Hence, early and timely recognition is of utmost importance in order to choose an appropriate therapeutic modality as well as to achieve better recovery and long-term survival. This case report discusses a case of 47-year-old woman who presented with a history of gradually worsening headaches and nasal discharge. The findings obtained from Contrast-Enhanced Computed Tomography (CECT) of the brain were indicative of clival chordoma with associated mass-effects and loco-regional spread. To the best of our knowledge, only a few cases of clival chordoma are reported from the Indian subcontinent.

\section{CASE REPORT}

A 47-year-old Indian woman, presented to the Department of Radiology with a history of gradually worsening headaches since eight months, and a history of nasal discharge since five months that raised with forced sneezing and coughing. The headache was moderate to severe with dull aching pain and spontaneous fluctuation in intensity. The pain was non-positional and partially relieved by paracetamol. Prior systemic medical history was non-contributory. She was disoriented and febrile when arrived at the clinic. For visual field testing and ophthalmologic examination, she was referred to an ophthalmologist. All ocular findings were normal. A few days later the patient underwent CECT of the brain using an ultra-fast multislice system. The CECT findings of the brain revealed a single ill-defined lesion with predominantly large soft tissue component causing lysis of the clivus and erosion of the skull base, measuring at least $4.5 \times 4.5 \times 6.5 \mathrm{~cm}$ in maximal orthogonal planes [Table/Fig-1a-c]. The postcontrast sequence showed avid enhancement. The lesion showed a patchy rim of calcification along the margins of the soft tissue.

Overall, the soft tissue component of the lesion was disproportionately large to the degree of bony destruction. The soft tissue extended contiguously into the sphenoid sinus and along the medial aspect of both infratemporal fossae. Posteriorly, the soft tissue was seen indenting on pons without invasion. Posteroinferiorly, the soft tissue extended along the nasopharynx and just about the soft palate. There was epidural extension of mass lesion in the middle cranial fossa causing inward buckling on right basal temporal lobe showing intracranial extension [Table/Fig-1d]. The optic chiasma and the pituitary gland appeared likely to be displaced superiorly by the masseffect from the lesion [Table/Fig-1e,f]. There was remarkable vascular recruitment from the surrounding brain parenchyma. The basilar artery was seen along the posterior margin of the lesion and did not show circumferential encasement. There was a reactive mucosal thickening/ opacification of the ethmoid air cells. Rest of the cerebral hemisphere was normal. Imaging features suggested the diagnosis of clival chordoma with associated mass-effects and loco-regional spread. The patients were referred to higher centre for further medical assistance.

\section{DISCUSSION}

Chordomas are rare slow-growing malignant bony tumours that are remnants of the notochord that stem from the bone and can advance anywhere along the craniospinal axis. They represent just
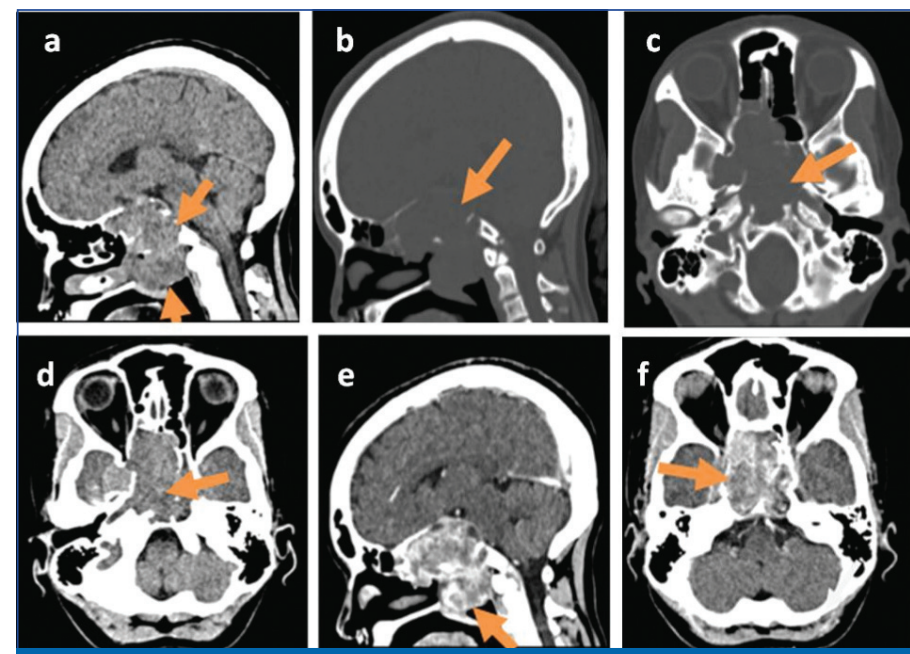

[Table/Fig-1]: Brain CT finding showing $(a, b, c)$ soft tissue attenuating mass lesion causing lytic destruction of clivus, sella tursica, body of sphenoid on right side

and extending into nasopharynx; (d) There is epidural extension of mass lesion in middle cranial fossa causing inward buckling on right basal temporal lobe showing intracranial extension; $(e, f)$ the lesion shows moderate hetereogenous postcontrast enhancement with some parts of mass lesion enhancing more as compared to other parts of mass lesion.

over $1 \%$ of intracranial tumours [1], and their prevalence is 0.08 per 100,000 individuals per year [2]. Histologically, chordoma are mainly classified into three types: a) chondroid; b) dedifferentiated; or c) classical [3]. Chordomas arise in the sacral (29.2\%), cranial (32\%) and spinal (32.8\%) regions [4]. Clival chordomas comprise about half of the cranial chordomas and these tumours are most frequently evident in women and younger patients [5].

In 1857, chordomas were first characterised microscopically by Virchow [6]. The manifestations of clival chordoma are mainly based upon the site of the tumour and the adjacent structures. The most typical manifestations of clival chordoma are headache, visual changes and cranial nerve palsies [7], whereas rare presentations include Cerebrospinal Fluid (CSF) rhinorrhoea and epistaxis [8]. Not only therapeutic challenges, but also diagnostic challenges are associated with chordomas. Diagnostic challenge is chiefly attributed to the rarity of the condition and tendency to involve any location within the craniospinal axis. As far as we know, in the literature, hardly a few cases have been reported on clival chordomas from the Indian subcontinent. Demographics and clinical manifestations of the present and earlier reported cases are compared in [Table/Fig-2] [9-15]. 


\begin{tabular}{|c|c|c|c|c|}
\hline Author, year & Age/Sex & Country & Presenting symptoms & Diagnosis \\
\hline Present case & $\begin{array}{l}\text { 47-year-old } \\
\text { female }\end{array}$ & India & $\begin{array}{l}\text { Headaches and nasal } \\
\text { discharge }\end{array}$ & $\begin{array}{l}\text { CECT findings of the brain revealed single ill-defined lesion with predominantly large soft } \\
\text { tissue component causing lysis of the clivus and erosion of the skull base measuring at least } \\
4.5 \times 4.5 \times 6.5 \mathrm{~cm} \text { in maximal orthogonal planes. The postcontrast sequence showed avid } \\
\text { enhancement. The lesion showed patchy rim of calcification along the margins of the soft } \\
\text { tissue. Overall, the soft tissue component of the lesion was disproportionately large to the } \\
\text { degree of bony destruction. The soft tissue extended contiguously into the sphenoid sinus } \\
\text { and along the medial aspect of both infratemporal fossae. Posteriorly, the soft tissue was } \\
\text { seen indenting on pons without invasion. Posteroinferiorly, the soft tissue extended along the } \\
\text { nasopharynx and just about the soft palate. There was epidural extension of mass lesion in the } \\
\text { middle cranial fossa causing inward buckling on right basal temporal lobe showing intracranial } \\
\text { extension. The optic chiasma and the pituitary gland appeared likely to be displaced superiorly } \\
\text { by the mass-effect from the lesion. There was remarkable vascular recruitment from the } \\
\text { surrounding brain parenchyma. The basilar artery was seen along the posterior margin of } \\
\text { the lesion and did not show circumferential encasement. There was a reactive mucosal } \\
\text { thickening/opacification of the ethmoid air cells. Rest of the cerebral hemisphere was normal. }\end{array}$ \\
\hline $\begin{array}{l}\text { Fink FM et al., } \\
1987 \text { [9] }\end{array}$ & $\begin{array}{l}\text { 9.5-year-old } \\
\text { girl }\end{array}$ & Austria & $\begin{array}{l}\text { Hoarseness, nausea, } \\
\text { repeated vomiting and no } \\
\text { headache }\end{array}$ & $\begin{array}{l}\text { X-ray showed soft nasopharyngeal masses on the lateral view of the skull. Cervical vertebral } \\
\text { X-ray of the column were normal. A skull CT scan revealed a giant tumour at the skull base. } \\
\text { A transoral biopsy revealed histology of a typical chordoma. }\end{array}$ \\
\hline $\begin{array}{l}\text { Goel AA et al., } \\
1996[10]\end{array}$ & $\begin{array}{l}7 \text { months } 16 \\
\text { days/boy }\end{array}$ & India & $\begin{array}{l}\text { Noisy breathing, snoring } \\
\text { and occasional apnoea with } \\
\text { cyanosis }\end{array}$ & $\begin{array}{l}\text { Magnetic Resonance Imaging (MRI) revealed a large retropharyngeal and clival mass. Histology } \\
\text { showed the typical characteristics of chordoma with tissue composed of lobules of large } \\
\text { clear physaliphora cells with small central or peripheral nuclei. Patient had comfortable and } \\
\text { soundless breathing and the neck position returned back to normal with no further episode of } \\
\text { apnoeic spell. }\end{array}$ \\
\hline $\begin{array}{l}\text { Khawaja AM } \\
\text { et al., } 2017 \\
{[11]}\end{array}$ & $\begin{array}{l}\text { 77-year-old } \\
\text { female }\end{array}$ & USA & Headaches and diplopia & $\begin{array}{l}\text { Sinuses CT scan revealed a large, expansile and erosive mass within the midline sphenoid } \\
\text { sinus (>3 cm in all dimensions). Isodense mass filled the sphenoid sinus completely, } \\
\text { destroying it inferiorly and extending into the right pneumatised pterygoid. Pneumatisedion of } \\
\text { the pterygoid process was noted, but did not accommodate the mass. The mass was also } \\
\text { eroding into the superior aspect of the clivus and extended into the posterior fossa. It showed } \\
\text { scattered calcifications, which were most likely the result of erosion of the native bone. Brain } \\
\text { MRI revealed a large mass involving the clivus and the sphenoid sinus, mainly on the right and } \\
\text { with the same features like CT scans. The mass was hyperintense on T2-weighted images, } \\
\text { mildly hypointense on T1-weighted images and demonstrated heterogeneous enhancement. }\end{array}$ \\
\hline $\begin{array}{l}\text { Chauhan A et } \\
\text { al., } 2017 \text { [12] }\end{array}$ & $\begin{array}{l}6 \text {-year-old } \\
\text { boy }\end{array}$ & India & $\begin{array}{l}\text { Dysphagia, regurgitation of } \\
\text { food, dysphonia with recent } \\
\text { dyspnoea. }\end{array}$ & $\begin{array}{l}\text { A well-defined lobulated lesion was observed, involving the skull central base with the } \\
\text { epicentre in the clivus/Basiocciput. On T2-weighted images, it is hyperintense with main } \\
\text { signals brighter as compared to the intervertebral discs. The lesion revealed foci with multiple } \\
\text { patchy low signal septations which included intermediate T1-weighted signals and elevated } \\
\text { Short Tau Inversion Signal (STIR) signals. Post-contrast enhancement is diverse, with septal } \\
\text { and peripheral enhancement with multiple relatively non-enhancing areas. Posteroinferiorly, } \\
\text { the lesion is infiltrating the foramen magnum with associated obliteration of anterior thecal } \\
\text { sac space and remarkable extradural compression of the cervicomedullary region of the brain } \\
\text { stem, appeared to be displaced to the left. The compressed brain stem segment revealed } \\
\text { increased T2/STIR signals. The proximal cervical spinal cord (up to the level corresponding to } \\
\text { the C2-C3 intervertebral disc) seems mildly swollen with hyperintense T2W/STIR signals (cord } \\
\text { oedema). Screening T2-weighted images of rest of the spine revealed normal morphology and } \\
\text { signal features. } \\
\text { On CT, an expansile osteolytic lesion was observed involving clival occipital bone (basiocciput) } \\
\text { with multiple areas of endosteal scalloping and marginal sclerosis, indicative of chronicity. } \\
\text { Lateral portion of the right occipital condyle, right jugular tubercle of the occipital bone and the } \\
\text { hypoglossal canal region were involved. The lesion revealed heterogeneous hypodense soft } \\
\text { tissue attenuation with mild and inhomogeneous postcontrast enhancement with patchy areas } \\
\text { of low attenuation and soft amorphous calcification within. Histopathological findings showed } \\
\text { chondroid component (hyaline cartilage) on histology indicating chordoma (chondroid type). }\end{array}$ \\
\hline $\begin{array}{l}\text { Erazo IS et al., } \\
2018 \text { [13] }\end{array}$ & $\begin{array}{l}\text { 15-year-old } \\
\text { female }\end{array}$ & Ecuador & $\begin{array}{l}\text { Severe pain in nasal region } \\
\text { and related headache, } \\
\text { nausea, dysphagia, otalgia, } \\
\text { strabismus of the left eye with } \\
\text { impaired visual acuity and } \\
\text { quadriparesis }\end{array}$ & $\begin{array}{l}\text { Brain and neck MRI showed an enhanced broad and destructive mass in the infrasellar area } \\
\text { with the entire destruction of the clivus, C1-C2 infiltration with compression of the occipital } \\
\text { foramen and displaced pons and medulla. }\end{array}$ \\
\hline $\begin{array}{l}\text { Munari S et } \\
\text { al., } 2020[14]\end{array}$ & $\begin{array}{l}\text { 20-year-old } \\
\text { girl }\end{array}$ & Italy & Asymptomatic & $\begin{array}{l}\text { A contrast-enhanced MRI scan with gadolinium demonstrated that the macroscopic residual } \\
\text { tumour at the level of jugular foramen which was exophytic in its intradural aspect, and the } \\
\text { bone CT scan confirmed the lytic areas of residual clivus infiltration. }\end{array}$ \\
\hline $\begin{array}{l}\text { Zribi A et al., } \\
2020 \text { [15] }\end{array}$ & $\begin{array}{l}\text { 26-year-old } \\
\text { man }\end{array}$ & Tunisia & $\begin{array}{l}\text { Orofacial paralysis and upper } \\
\text { limbs paresthesia }\end{array}$ & $\begin{array}{l}\text { Cerebral CT-scan showed a locally advanced } 58 \mathrm{~mm} \text { osteolytic tumour in the mid clivus. The } \\
\text { tumour invaded the oropharynx, the para-pharyngeal spaces and the spinal canal with brain } \\
\text { stem compression. Cerebro-spinal MRI demonstrated a locally aggressive lesion of the clivus } \\
\text { invading the right cavernous sinus, T1 isointense and T2 hyperintense with heterogeneous } \\
\text { enhancement on post-contrast images. Hematoxylin and eosin stained sections revealed } \\
\text { a feature of epithelioid and partially physaliferous tumour cells arranged in lobules. Lobules } \\
\text { were separated by thin fibrous septae embedded within a myxoid matrix resembling } \\
\text { neoplastic hyaline cartilage. Immunohistochemical staining demonstrated strong positivity for } \\
\text { pancytokeratin. Tumour cells reveled a weak cytoplasmic and nuclear positivity for S-100. }\end{array}$ \\
\hline
\end{tabular}

Differential diagnosis can be made using multiple imaging modalities. On plain radiographs, local bony erosion and scattered calcifications are observed. CT findings showed reduced attenuation and hyperdense regions. It may also exhibit the erosion of neighbouring structures and an inner calcified matrix. Brain MRI showed typical characteristics of bony expansion together with hypointensity on T1-weighted images and hyperintensity on T2-weighted images. Heterogeneous enhancement pattern on T1-weighted images following administration of gadolinium may also be noted. Perioperative biopsy using multiple analytical techniques is useful to confirm the diagnosis. For all skull base tumours, CT scan and MRI are the gold standards for diagnosis. As compared to $\mathrm{MRI}, \mathrm{CT}$ scan is better in illustrating tumoural calcification and associated bone destruction. As chordoma originates along the craniospinal axis, spine imaging is required to rule out lesions elsewhere, however it was not done in the present case.

Surgical intervention is the recommended treatment modality having a goal to achieve a gross total resection of the tumour. Conventionally, clival chordomas can be managed by transcranial, 
transsphenoidal, transoropharyngeal and maxillary osteotomy approaches [16]. At present, endoscopic surgery has been an emerging avenue for managing clival chordomas. Recently, Imatinib, a tyrosine kinase inhibitor, was endorsed as a monotherapy for chronic myelogenous leukaemia. Imatinib has been investigated in chordomas as its use has been associated with not only tumour liquefaction but also decreased density of chordomas expressing the Platelet-Derived Growth Factor Receptor-Beta (PDGFR $\beta$ ) [17]. Also, radiotherapy is the mainstay in treating chordomas. In the literature, multiple modalities have been reported varying from proton-beam radiotherapy to recent ones such as fractionated photon radiotherapy, carbon-ion radiotherapy and stereotactic radiosurgery.

\section{CONCLUSION(S)}

The authors opine that timely and early detection of clival chordomas is of great importance for gaining better local control over these gradually progressive tumours and long term survival.

\section{REFERENCES}

[1] Berryhill BH, Armstrong BW. Extracranial presentation of craniocervical chordoma. Laryngoscope. 1984;94:1063-65.

[2] McMaster ML, Goldstein AM, Bromley CM, Ishibe N, Parry DM. Chordoma: Incidence and survival patterns in the United States, 1973-1995. Cancer Causes Control. 2001;12:01-11.

[3] Heffelfinger MJ, Dahlin DC, MacCarty CS, Beabout JW. Chordomas and cartilaginous tumours at the skull base. Cancer. 1973;32:410-20.

[4] Mendenhall WM, Mendenhall CM, Lewis SB, Villaret DB, Mendenhall NP. Skull base chordoma. Head Neck. 2005;27:159-65.
[5] Noel G, Habrand JL, Jauffret E, de Crevoisier R, Dederke S, Mammar H, et al. Radiation therapy for chordoma and chondrosarcoma of the skull base and cervical spine. Prognostic factors and patterns of failure. Strahlenther Onkol. 2003;179:241-48

[6] Virchow RLK. Untersuchungen Über Die Entwickelung Des SchädelgrunDes Im GesUnDen Und Krankhaften Zustand: Und Über Den Einfluss Derselben Auf Schädelform, Gesichtsbildung und Gehirnbau, Berlin, Germany, 1857 (Development of the Base of the Skull Healthy And Diseased Condition: And About Its Influence On Skull shape, face formation and brain structure, Berlin, Germany, 1857).

[7] Michele SM, Samuel CL. Chordomas of the skull base: Manifestations and management. Curr Opin Otolaryngol Head Neck Surg. 2003;11:324-27.

[8] Kitai R, Yoshida K, Kubota T, Sato K, Handa Y, Kasahara K, et al. Clival chordoma manifesting as nasal bleeding. A case report. Neuroradiology. 2005;47:368-71.

[9] Fink FM, Ausserer B, Schröcksnadel W, Pallua AK, Frommhold H, Mikuz G. Clivus chordoma in a 9-year-old child: Case report and review of the literature. Pediatr Hematol Oncol. 1987;4:91-100.

[10] Goel AA, Nadkarni TD, Kirtane MV. Clival chordoma in an infant. J Postgrad Med. 1996;42:51.

[11] Khawaja AM, Venkatraman A, Mirza M. Clival chordoma: Case Report and Review of Recent Developments in Surgical and Adjuvant Treatments. Pol J Radiol. 2017;17:82:670-75.

[12] Chauhan A, Ahluwalia W, Saharan PS, Sharma N, Narayan S, Gupta R. Clival chordoma in a young child. Appl Radiol. 2017;46:37-41.

[13] Erazo IS, Galvis CF, Aguirre LE, Iglesias R, Abarca LC. Clival chondroid chordoma: A case report and review of the literature. Cureus. 2018;10(9):e3381.

[14] Munari S, Colangeli R, Ramacciotti G, Zanoletti E. Clivus chordoma: Case Report and Current Considerations on Treatment Strategies. J Int Adv Otol. 2020;16:286-90.

[15] Zribi A, Nasr SB, Khemir A, Gargouri F, Abdallah IB, Msakni I, et al. Clival chordoma in a young male patient: A case report. Pan Afr Med J. 2020;37:59.

[16] Jiang WH, Zhao SP, Xie ZH, Zhang H, Zhang J, Xiao JY, et al. Endoscopic resection of chordomas in different clival regions. Acta Otolaryngol. 2009;129:71-83.

[17] Casali PG, Messina A, Stacchiotti S, Tamborini E, Crippa F, Gronchi A, et al. Imatinib mesylate in chordoma. Cancer. 2004;101:2086-97.

\section{PARTICULARS OF CONTRIBUTORS:}

1. Consultant Radiologist, Department of Radiology, Shukla Diagnostic Center, Balaghat, Madhya Pradesh, India

2. Consultant Radiologist, Department of Radiology, Shukla Diagnostic Center, Balaghat, Madhya Pradesh, India.

3. Medical Writer, Department of Clinical Research, Shukla Diagnostic Center, Balaghat, Madhya Pradesh, India.

NAME, ADDRESS, E-MAIL ID OF THE CORRESPONDING AUTHOR:

Dr. Akshat Sanjay Shukla,

Consultatnt Radiologist, Department of Radiology, Shukla Diagnostic Center,

Balaghat-480001, Madhya Pradesh, India.

E-mail: akshat.shukla006@gmail.com

\section{AUTHOR DECLARATION}

- Financial or Other Competing Interests: None

- Was informed consent obtained from the subjects involved in the study? Yes

- For any images presented appropriate consent has been obtained from the subjects. Yes
PLAGIARISM CHECKING METHODS: [Jain H et al.]

- Plagiarism X-checker: Apr 07, 2021

- Manual Googling: May 25, 2021

- iThenticate Software: Jul 14, 2021 (19\%)
ETYMOLOGY: Author Origin

Date of Submission: Apr 06, 2021

Date of Peer Review: May 07, 2021

Date of Acceptance: May 26, 2021

Date of Publishing: Oct 01, 2021 